\title{
Validity of the portuguese version of the mini nutritional assessment in brazilian elderly
}

\author{
Renata Santos Pereira Machado ${ }^{1 *}$, Maria Auxiliadora Santa Cruz Coelho ${ }^{1}$ and Renato Peixoto Veras ${ }^{2}$
}

\begin{abstract}
Background: Malnutrition is common and affects negatively the health of the older adult. The Mini Nutritional Assessment (MNA), a nutritional assessment tool allows to identify elders malnourished and at risk of malnutrition. The aim of this study is to validate the Portuguese version of the MNA.

Methods: Cross-sectional study with 344 Brazilian elderly. The full version of the MNA was performed, also calf circumference (CC), mid arm circumference (MAC) and body fat (BF). Psychometric evaluation was carried out and correlation, diagnostic accuracy and ROC curves were generated.

Results: Construct validity was supported, all four questionnaire dimensions were evidenced in the Principal Component Analysis and also significant Spearman correlation $(P<0.001)$ were demonstrated. Criterion validity was also evidenced with relevant sensitivity (MAC $=82.8 ; \mathrm{C} 195 \%=64.2-94.2)$ and specificity $(C C=80.0 ; C 195 \%=74.0-85.1)$. In the ROC curve AUC was excellent (MAC $=0.832 ; \mathrm{Cl} 195 \%=0.785-0.873$ ).

Conclusions: The full MNA demonstrated significant results and sufficient exploratory psychometric properties that supported its validity. It seems to be valid tool to access nutritional status of Brazilian elderly.
\end{abstract}

Keywords: Elderly, Malnutrition, Mini nutritional assessment, Validation, Accuracy

\section{Background}

Malnutrition is common and affects negatively the health of the older adult. It can lead to various health concerns, including a weak immune system, poor wound healing, muscle weakness and also disinterest in eating or lack of appetite. Malnutrition is often caused by a combination of physical, social and psychological issues. It is more common and increasing in the older population; currently $16 \%$ of those $>65$ years and $2 \%$ of those $>85$ years are classed as malnourished. Almost two-thirds of general and acute hospital beds are used by people aged $>65$ years [1-3]. As the research statistics indicate, not only is malnutrition prevalent in the elderly, it is also frequently misdiagnosed or unrecognized. Many health care professionals are not properly screening or assessing malnutrition in the elderly $[2,4]$.

\footnotetext{
* Correspondence: renata_nut@hotmail.com

'Instituto de Nutrição Josué de Castro - INJC, Universidade Federal do Rio de Janeiro - UFRJ, Av. Carlos Chagas Filho, 373 - Ed. do Centro de Ciências da Saúde, Bloco J / $2^{\circ}$ andar. Cidade Universitária, Ilha do Fundão, Rio de Janeiro, RJ 21941-902, Brasil

Full list of author information is available at the end of the article
}

The Mini Nutritional Assessment (MNA), a nutritional assessment tool widely used around the world, allows to identify elders malnourished and at risk of malnutrition. It has been translated in over 20 languages with more than 600 PUBMED references $[5,6]$. The MNA consists of 18 items including anthropometric, global, dietetic and subjective assessment dimensions. Currently the MNA is used in clinical practice and clinical research $[7-10]$ to assess community-dwelling older adults [11, 12], hospitalized patients [13] or nursing home residents $[8,14,15]$.

Studies about malnutrition in the elderly using the MNA in Brazil are insufficient and no validation study has been developed there yet. It very is important to do nutritional assessment in the elderly, making use of valid tools.

The purpose of this article is to validate the Portuguese version of the Mini Nutritional Assessment in Brazilian elderly. 


\section{Method}

Participants

This was a cross-sectional study, conducted with institutionalized elderly residents in public long term geriatric units in Rio de Janeiro, Brazil as part of a larger observational study of nutritional assessment.

Elderly aged 60 year or older were eligible, as recommended by the World Health Organization (WHO) for developing countries such as Brazil [16]. It was also an inclusion criteria have being able to communicate and the strength to carry out an interview and give written informed consent. The exclusion criteria were to suffer from cognitive impairment and not to accept to take part in the survey. The survey consisted of 344 elderly that were residents in one of the 12 municipal shelters in Rio de Janeiro, aged 60-117 years old, $41 \%$ of men and $59 \%$ women and the data were collected in 2001. All included participants provided informed consent.

\section{Nutritional assessment}

The full-form MNA was administered by trained nutritionists, despite the score in the first part of the test. The score range from 0 to 30 , and it was calculated as the sum of the values from the 18 items. An MNA score of 24 or higher identifies the patient with a good nutritional status, scores between 17 and 23.5 indicates patients at risk for malnutrition and score less than 17 identifies patients with protein-caloric malnutrition [17].

The anthropometric assessment that were carried out included body weight and height [18], arm span [19], calf circumference (CC) [20], mid arm circumference (MAC) [21] and bioimpedance electric (BIO).

Weight was measured to the nearest $0.1 \mathrm{~kg}$, with the subject in light clothes and no shoes, using a digital scale Kratos with a maximum capacity of $150 \mathrm{~kg}$. Height was measured to the nearest $0.1 \mathrm{~cm}$ using a vertical stadiometer Leicester, with the subject's bare feet close together, back and heels against the wall, standing erect and looking straight ahead. To measure MAC the mid-point between the tip of the acromion and the olecranon process was marked while the subject held the forearm in horizontal position. The measurement was performed on the subject's arm hanging freely along the trunk with a flexible inextensible tape. CC was measured at the maximal circumference between the ankle and the knee with a flexible tape measure, manipulated to maintain close contact with the skin without compression of underlying tissues. These measures were performed on the non-dominant arm and leg.

In order to classify under nutrition, to BMI it was used the cut-off proposed by the World Health Organization for the elderly [16]. The BMI [weight (kg)/height (m2)] was classified by using the WHO cut-off points, considering women and $<23 \mathrm{~cm}$ for men, were used to predict under-nutrition [22] and to $\mathrm{CC}<31$ [16]. To percentage of body fat values the cut-off points were $<24 \%$ for women and $<13 \%$ for man [23].

MAC and CC are parameters used for measurement of muscle mass and subcutaneous adipose tissue [24] and a low MAC among the elderly has been shown to increase risk of mortality and indicates loss of peripheral muscle mass $[25,26]$. As for CC, a value of less than $31 \mathrm{~cm}$ will indicate muscle loss especially in the lower limb [16]. Body composition was assessed by bioelectric bioimpedance. Fat-free mass, total body fat and per cent body fat were determined.

\section{Statistical analyses}

Descriptive results are presented as means and standard deviations, frequencies and $95 \%$ confidence intervals (CI $95 \%$ ). The analysis of data involved descriptive statistics such as mean, standard deviation (SD) and simple frequency. It was used analysis of variance (ANOVA) to compare means between the continuous variables.

To validity it was assessed construct validity and criterion validity, according to Streiner \& Norman (2008) [27]. Spearman's rank correlation coefficients between total MNA score obtained and the criteria of BMI, MAC, CC and BF were calculated. Also measures of accuracy of the tests, sensitivity, specificity, and areas under ROC curves (AUC) were calculated (CI95\%). Classification of AUC (range 0-1): acceptable 0.70-0.80, excellent 0.80-0.90, outstanding >0.90 [28].

Exploratory factor analysis with principal components extraction was performed, using PROMAX Rotation with Kaiser Normalization applied to the component matrix.

Significance statistics was considered with $\mathrm{p}<0.05$. Statistical analyses were performed with IBM SPSS Statistics 19 (SPSS Inc. Chicago IL, USA). Graphics for ROC analyses were created with MedCalc version 12.7.

\section{Ethics}

The local ethics committee of the Federal University of Rio de Janeiro - UFRJ, approved the study protocol. All participants gave written informed consent.

\section{Results}

A total of 344 subjects were evaluated. The full MNA classified $36.1 \%$ of participants in the total data set well nourished, $55.6 \%$ as at risk, and $8.3 \%$ as malnourished. Total MNA scores averaged 22.3 (SD 3.6) and ranged from a minimum of 10.0 to a maximum of 29.0. The age range of the subjects was between 60 and 117 years old with a mean age of 75.4 (SD 9.4) years old. 
The socio-demographic profile indicated similarity in the marital status and income of men and women. In relation to age, women have higher prevalence in the older age group and also higher prevalence in the range of education with fewer years of study (Table 1). Nutritional assessment according to MNA is shown in Table 2, with statistical significance for weight, BF, $\mathrm{MAC}, \mathrm{CC}$ and BMI.

The Kayser-Meyer-Olkin (KMO) measure was 0.64. When above 0.5 it shows an adequation of the method. The Bartletts Test of Sphericity was 623.706, $\mathrm{df}=153$ and $p=0.000$, indicating that the sample was adequate for conducting Factor Analysis.

Table 1 Socio-demographic and anthropometrics characteristics of subjects according to sex

\begin{tabular}{|c|c|c|c|c|}
\hline & Men & Women & Total & $p$-value \\
\hline & $\mathrm{N}(\%)$ & N (\%) & $\mathrm{N}(\%)$ & \\
\hline \multicolumn{5}{|l|}{ Age } \\
\hline$<70$ & $53(37.9)$ & $53(26.0)$ & $106(30.8)$ & $0.013^{*}$ \\
\hline$>=70$ & $87(62.1)$ & $151(79.0)$ & $238(69.2)$ & \\
\hline \multicolumn{5}{|l|}{ Marital status } \\
\hline Married & $14(10.0)$ & $11(5.4)$ & $25(7.3)$ & 0.081 \\
\hline Not married & $126(90.0)$ & $193(94.6)$ & $319(92.7)$ & \\
\hline \multicolumn{5}{|l|}{ Years of Education } \\
\hline$<=4$ & $70(50.0)$ & $138(67.6)$ & $208(60.5)$ & $0.001^{*}$ \\
\hline$>4$ & $70(50.0)$ & $66(32.4)$ & $136(39.5)$ & \\
\hline \multicolumn{5}{|l|}{ Income } \\
\hline$<2$ minimum wage & $98(90.7)$ & $136(88.9)$ & $234(89.7)$ & 0.384 \\
\hline $2+$ minimum wage & $10(9.3)$ & $17(11.1)$ & $27(10.3)$ & \\
\hline \multicolumn{5}{|l|}{ MNA } \\
\hline Malnutrition & 8 (6.6) & $17(9.4)$ & $25(8.3)$ & 0.242 \\
\hline At risk of malnutrition & $72(59.0)$ & $96(53.3)$ & $168(55.6)$ & 0.246 \\
\hline Well nourished & $42(34.4)$ & $67(37.2)$ & 109 (36.1) & \\
\hline \multicolumn{5}{|l|}{ BMI } \\
\hline Underweigth & 54 (38.6) & $54(26.5)$ & $108(31.4)$ & $0.012^{*}$ \\
\hline Normal & $86(61.4)$ & $150(73.5)$ & $236(98.6)$ & \\
\hline \multicolumn{5}{|l|}{ MAC } \\
\hline Underweigth & $8(5.7)$ & $24(11.8)$ & $32(9.3)$ & $0.041^{*}$ \\
\hline Normal & 132 (94.3) & $180(88.2)$ & 312 (90.7) & \\
\hline \multicolumn{5}{|l|}{$\mathrm{CC}$} \\
\hline Underweigth & $22(17.9)$ & $56(29.8)$ & $78(25.1)$ & $0.012^{*}$ \\
\hline Normal & 101 (82.1) & $132(70.2)$ & $233(74.9)$ & \\
\hline \multicolumn{5}{|l|}{ PBF } \\
\hline Underweigth & $29(24.4)$ & $50(27.3)$ & 79 (26.2) & 0.333 \\
\hline Normal & $90(75.6)$ & $133(72.7)$ & $233(73.8)$ & \\
\hline
\end{tabular}

MNA mini nutritional assessment, $B M I$ body mass index, $M A C$ mid-arm circumference, $C C$ calf circumference, $P B F$ percentage of body fat ${ }^{*} p<0.05$, significance level difference between sex (ANOVA)
Table $\mathbf{2}$ Characteristics of nutritional assessment according to the Portuguese version of the MNA

\begin{tabular}{|c|c|c|c|c|c|c|c|}
\hline & \multicolumn{7}{|c|}{ MNA } \\
\hline & \multicolumn{2}{|c|}{ Malnutrition } & \multicolumn{2}{|c|}{$\begin{array}{l}\text { At risk of } \\
\text { malnutrition }\end{array}$} & \multicolumn{2}{|c|}{ Well nourished } & \multirow[t]{2}{*}{$\begin{array}{l}p^{-} \\
\text {value }\end{array}$} \\
\hline & $\bar{N}$ & Mean (DP) & $\mathrm{N}$ & Mean (DP) & $\mathrm{N}$ & Mean (DP) & \\
\hline Age (y) & 25 & $\begin{array}{l}76,68 \\
(10,49)\end{array}$ & 168 & $76,1(9,15)$ & 109 & $73,61(9,52)$ & 0,072 \\
\hline $\begin{array}{l}\text { Height } \\
(\mathrm{cm})\end{array}$ & 24 & $\begin{array}{l}151,70 \\
(8,77)\end{array}$ & 157 & $\begin{array}{l}155,40 \\
(10,71)\end{array}$ & 108 & $\begin{array}{l}155,62 \\
(10,36)\end{array}$ & 0,233 \\
\hline $\begin{array}{l}\text { Weight } \\
(\mathrm{Kg})\end{array}$ & 24 & $\begin{array}{l}50,70 \\
(12,37)\end{array}$ & 157 & $\begin{array}{l}55,82 \\
(11,80)\end{array}$ & 108 & $\begin{array}{l}65,99 \\
(14,79)\end{array}$ & $0,000^{*}$ \\
\hline $\begin{array}{l}\text { Body fat } \\
(\mathrm{Kg})\end{array}$ & 22 & $\begin{array}{l}22,27 \\
(10,96)\end{array}$ & 149 & $\begin{array}{l}22,53 \\
(10,17)\end{array}$ & 104 & $\begin{array}{l}28,24 \\
(10,12)\end{array}$ & $0,000^{*}$ \\
\hline $\operatorname{MAC}(\mathrm{cm})$ & 23 & $\begin{array}{l}25,05 \\
(4,26)\end{array}$ & 157 & $26,94(4,27)$ & 105 & $29,65(4,93)$ & $0,000^{*}$ \\
\hline$C C(\mathrm{~cm})$ & 24 & $\begin{array}{l}30,46 \\
(3,23)\end{array}$ & 156 & $32,80(4,26)$ & 104 & $35,52(4,93)$ & $0,000^{*}$ \\
\hline $\begin{array}{l}\text { BMI } \\
(\mathrm{m} / \mathrm{Kg} 2)\end{array}$ & 24 & $\begin{array}{l}22,01 \\
(4,89)\end{array}$ & 157 & $23,17(4,79)$ & 108 & $27,29(5,75)$ & $0,000^{*}$ \\
\hline
\end{tabular}

MNA mini nutritional assessment, $B M I$ body mass index, $M A C$ mid-arm circumference, $C C$ calf circumference,

${ }^{*} p<0.05$, significance level difference between MNA (ANOVA)

In the Principal Component Analysis of the MNA, the results show a dispersion of the items for 6 components. It explains $52.6 \%$ of the total variance in the explanatory psychometric evaluation. All four dimensions of the MNA are evidenced in the component analysis. The items are arranged according to the dimensions proposed in the original questionnaire, defining the constructs. The anthropometric assessment dimension corresponds to component 1; the global assessment dimension to component 4 ; the dietetic dimension to component 5 ; and the subjective dimension to component 2 (Table 3).

Table 4 shows significant score correlations of the dimensional items of the MNA questionnaire, except for independence at home and number of meals per day.

All nutritional variables had correlation with the full MNA (Fig. 1). There is strong and significant correlation between $\mathrm{BF}, \mathrm{CC}, \mathrm{MAC}, \mathrm{BMI}$ and the MNA in this study population.

The ROC curve is presented in Fig. 2, as well as the corresponding AUC values. In this study, MAC provided excellent discrimination and the other anthropometric measures acceptable discrimination values (Table 5). All indicators showed good sensibility and specificity. MAC was more sensitive (82.8; CI95\% 64.2-94.2) and CC more specific (80.0; CI95\% 74.0-85.1).

\section{Discussion}

MNA is used widely around the world to evaluate nutrition status of the elderly. Other studies show that the 
Table 3 Structure matrix of principal component analysis of the mini nutritional assessment questionnaire variables

\begin{tabular}{|c|c|c|c|c|c|c|c|}
\hline \multirow[t]{2}{*}{ Area } & \multirow[t]{2}{*}{ Item content } & \multicolumn{6}{|c|}{ Component } \\
\hline & & 1 & 2 & 3 & 4 & 5 & 6 \\
\hline \multirow[t]{4}{*}{ Anthropometric assessment } & Body mass index & 0,853 & 0,140 & 0,090 & $-0,015$ & $-0,006$ & 0,066 \\
\hline & Mid-arm circumference & 0,805 & 0,070 & 0,107 & 0,023 & 0,078 & 0,016 \\
\hline & Calf circumference & 0,775 & 0,121 & 0,189 & 0,054 & 0,033 & $-0,032$ \\
\hline & Weight loss & $-0,036$ & 0,720 & $-0,045$ & 0,079 & 0,050 & $-0,095$ \\
\hline \multirow[t]{6}{*}{ Global assessment } & Independence at home & 0,066 & $-0,070$ & 0,028 & 0,127 & $-0,077$ & 0,702 \\
\hline & Number of medication per day & $-0,169$ & $-0,044$ & 0,008 & 0,575 & $-0,268$ & $-0,063$ \\
\hline & Psycological stress & 0,051 & 0,203 & $-0,034$ & 0,523 & 0,181 & 0,154 \\
\hline & Mobility & 0,085 & 0,032 & 0,698 & 0,132 & $-0,055$ & $-0,120$ \\
\hline & Neuropsychological problems & $-0,075$ & 0,346 & 0,491 & 0,125 & $-0,032$ & $-0,458$ \\
\hline & Pressure skin ulcer & 0,129 & 0,153 & 0,025 & 0,648 & 0,114 & $-0,059$ \\
\hline \multirow[t]{6}{*}{ Dietetic assessment } & Number of meals per day & $-0,127$ & 0,038 & 0,071 & $-0,250$ & 0,374 & 0,357 \\
\hline & Serves of high-protein foods & 0,009 & 0,165 & 0,076 & 0,051 & 0,735 & $-0,111$ \\
\hline & Fruit and vegetables intake & 0,037 & 0,087 & $-0,010$ & 0,069 & 0,697 & $-0,009$ \\
\hline & Fluid intake & 0,047 & 0,067 & 0,319 & 0,458 & 0,272 & $-0,464$ \\
\hline & Mode of feeding & 0,202 & 0,013 & 0,663 & $-0,200$ & 0,167 & 0,166 \\
\hline & Appetite & 0,174 & 0,711 & $-0,095$ & 0,240 & 0,259 & $-0,055$ \\
\hline \multirow[t]{2}{*}{ Subjective assessment } & Self-rated nutritional status & 0,181 & 0,697 & 0,350 & 0,163 & 0,097 & $-0,093$ \\
\hline & Self-rated health & 0,146 & 0,475 & 0,356 & $-0,083$ & 0,059 & $-0,360$ \\
\hline
\end{tabular}

Rotation Method: Promax with Kaiser Normalization

MNA is an accurate assessment tool for nutritional problems, however it was not validated yet for Brazilian or other Latin American population [17, 29].

In the present study we used anthropometric measures including BMI, MAC, CC and BF. Even though there are not currently, generally accepted criteria for the diagnosis of malnutrition, these parameters have been widely used to evaluate nutritional status [30].

According to these testing results, the MNA full version was shown to have sufficient evidence of validity, including sensitivity and specificity in a sample of older home dwelling people, for identifying elderly hospital at nutritional risk and malnutrition. Anthropometric measures were used as standard to assess concurrent validity and to estimate sensitivity and specificity values.

Validity was supported when testing construct validity, when there is objective criterion that can be used. The Principal Component analysis was robust, with all dimensions represented and with significant correlations. Almost all item-to-total correlations were statically significant. However, not for two of the correlation coefficients: independence at home and number of meals per day. It can be explained by the fact that most of the people in this study gave the same answer, that is, they had the same meals and were not independent at home.

Criterion validity was also supported. It answers the question of how well the scores on a test agree
Table 4 Item-total score correlations (Spearman, r) for the Portuguese version of the Mini Nutritional Assessment

\begin{tabular}{|c|c|c|c|}
\hline Area & Item content & $r$ & $\begin{array}{l}P \text { - } \\
\text { value }\end{array}$ \\
\hline \multirow{4}{*}{$\begin{array}{l}\text { Anthropometric } \\
\text { assessment }\end{array}$} & Body mass index & 0,468 & 0,000 \\
\hline & Mid-arm circumference & 0,380 & 0,000 \\
\hline & Calf circumference & 0,430 & 0,000 \\
\hline & Weight loss & 0,512 & 0,000 \\
\hline \multirow[t]{6}{*}{ Global assessment } & Independence at home & $-0,190$ & 0,746 \\
\hline & $\begin{array}{l}\text { Number of medications } \\
\text { per day }\end{array}$ & 0,115 & 0,046 \\
\hline & Psychological stress & 0,339 & 0,000 \\
\hline & Mobility & 0,289 & 0,000 \\
\hline & $\begin{array}{l}\text { Neuropsychological } \\
\text { problems }\end{array}$ & 0,316 & 0,000 \\
\hline & Pressure skin ulcers & 0,314 & 0,000 \\
\hline \multirow[t]{6}{*}{ Dietetic assessment } & Number of meals per day & 0,033 & 0,563 \\
\hline & $\begin{array}{l}\text { Serves of high-protein } \\
\text { foods }\end{array}$ & 0,183 & 0,001 \\
\hline & Fruit and vegetables intake & 0,242 & 0,000 \\
\hline & Fluid Intake & 0,326 & 0,000 \\
\hline & Mode of feeding & 0,218 & 0,000 \\
\hline & Appetite & 0,489 & 0,000 \\
\hline \multirow[t]{2}{*}{ Subjective assessment } & Self-rated nutritional status & 0,528 & 0,000 \\
\hline & Self-rated health & 0,416 & 0,000 \\
\hline
\end{tabular}




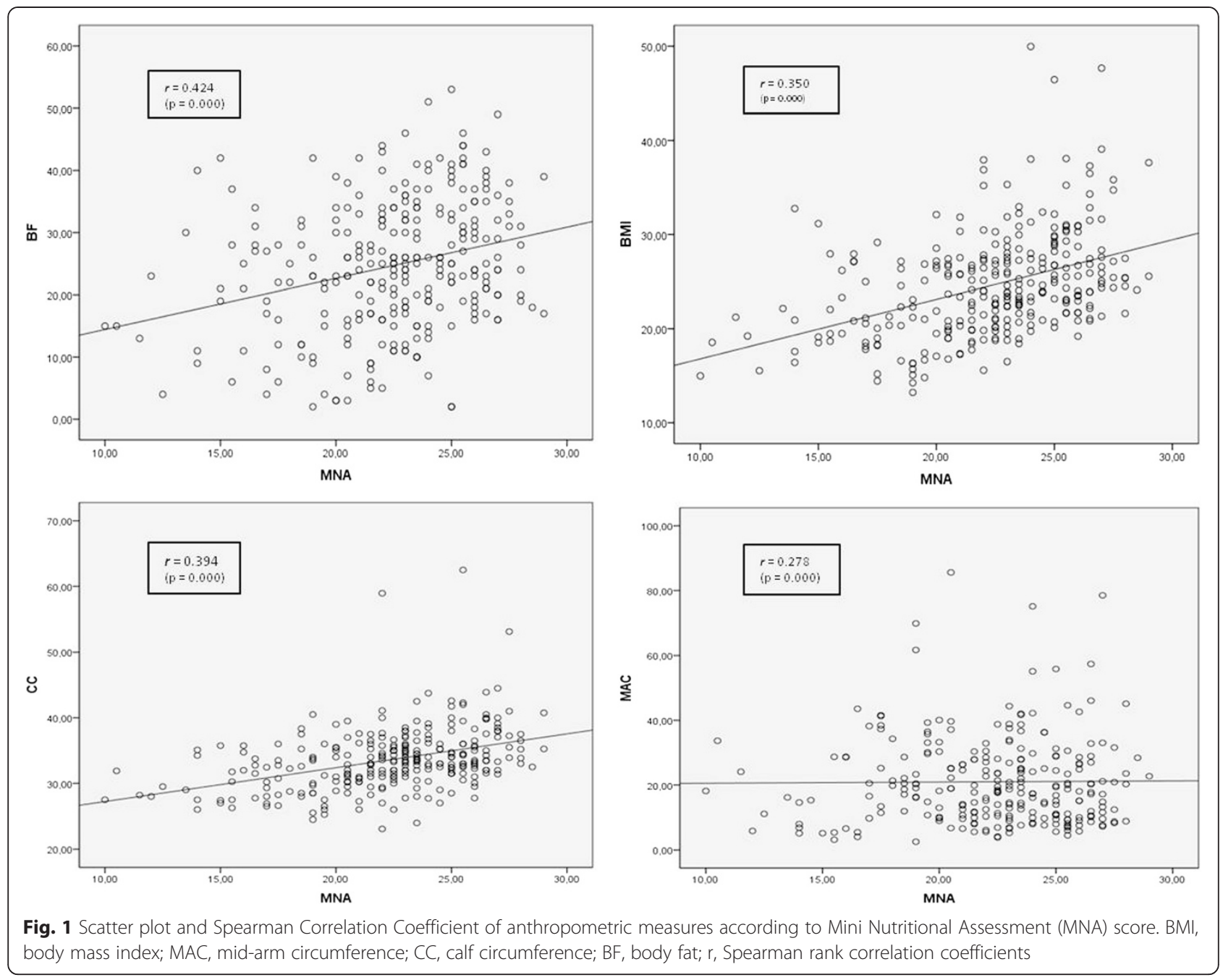

with performance on a task it was meant to predict. The test had significant values of AUC, sensibility and specificity when the criteria BMI, MAC and CC were used. These criteria are common anthropometric measurements and often used in nutritional assessments [31].

According to the American Journal of Nursing, nine studies report sensitivity of the MNA to be $70 \%$ or higher, compared with other nutritional parameters [32-40], similar to this study results. In the original study of MNA as an indicator of protein-calorie under nutrition was found to have a sensitivity of $96 \%$ and specificity of $98 \%$ [17]; however we found lower sensitivity and specificity among Brazilian elderly, but still solid results. Based on the observation of the ROC curve, we also showed that the MNA is accurate.

Some limitations of this study deserve mentioning. First, due to the cross-sectional nature of this study we were unable to estimate a relative risk. Second, in order to increase the possibility of generalization, this association should be studied also in a free living sample. Nevertheless, this study is an important step in supporting scientific using of a popular instrument that measures risk and malnutrition in the elderly.

\section{Conclusion}

In conclusion, various studies support the use of MNA through the world among the elderly population. Malnutrition leads to a decline in health and possibly death; it is often unrecognized and under-treated by healthcare professionals. The full Portuguese version of the MNA demonstrated significant results that supported its validity. MNA has also shown robust exploratory psychometric properties for performing a nutritional screening. It seems to be valid tool to access nutritional status of Brazilian elderly. 

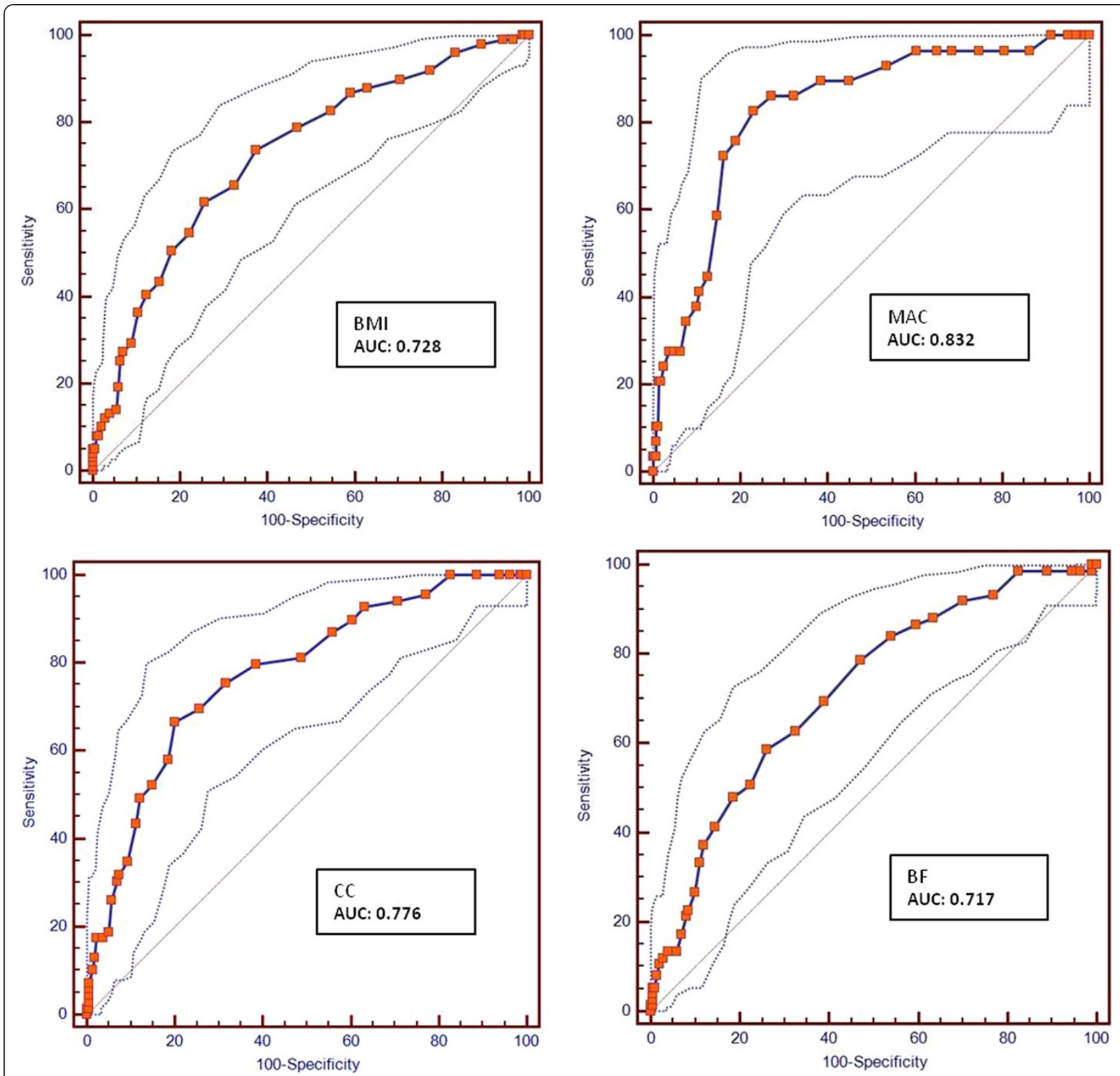

Fig. 2 ROC curves of the Portuguese Mini Nutritional Assessment according to anthropometric measures. BMl, body mass index; MAC, mid-arm circumference; CC, calf circumference; BF, body fat; AUC, area under roc curve

Table 5 Accuracy the Portuguese version of the mini nutritional assessment tool according to BMI, MAC, CC and BF

\begin{tabular}{lllll}
\hline Measure & Sensitivity $(95 \% \mathrm{Cl})$ & Specificity $(95 \% \mathrm{Cl})$ & AUC $(95 \% \mathrm{Cl})$ & AUC discrimination \\
\hline BMI & $73.7(63.9-82.1)$ & $62.6(55.5-69.2)$ & $0.728(0.674-0.777)$ & acceptable \\
MAC & $82.8(64.2-94.2)$ & $76.9(71.5-81.8)$ & $0.832(0.785-0.873)$ & excellent \\
CC & $66.7(54.3-77.6)$ & $80.0(74.0-85.1)$ & $0.776(0.723-0.823)$ & acceptable \\
BF & $58.7(46.7-64.9)$ & $74(67.3-79.9)$ & $0.717(0.660-0.769)$ & acceptable \\
\hline
\end{tabular}

$B M I$ body mass index, $M A C$ mid-arm circumference, $C C$ calf circumference, $B F$ body fat, $C l$ confidence interval, $A U C$ area under roc curve, $r$ spearman rank correlation coefficients 


\section{Abbreviations}

MNA: Mini Nutritional Assessment; CC: Calf circumference; MAC: Mid arm circumference; BF: Body fat; BIO: Bioimpedance electric; BMI: Body mass index; r: Spearman correlation coefficient; ANOVA: Variance analysis; SD: Standard deviation; AUC: Area under ROC curve.

\section{Competing interests}

The authors declare that they have no competing interests.

\section{Authors' contributions}

SPM, R. conceived the study, data analysis, statistical analysis, and drafted the manuscript. PV, R. and SCC, M.A. made a substantial contribution to the analysis and interpretation of the data, and to the final writing of the paper. All authors read and approved the final manuscript.

\section{Acknowledgements}

We appreciate the reviewers for comments that have improved the manuscript. This work was supported by FAPERJ - Fundação Carlos Chagas Filho de Amparo à Pesquisa do Estado do Rio de Janeiro.

\section{Author details}

'Instituto de Nutrição Josué de Castro - INJC, Universidade Federal do Rio de Janeiro - UFRJ, Av. Carlos Chagas Filho, 373 - Ed. do Centro de Ciências da Saúde, Bloco $\mathrm{J} / 2^{\circ}$ andar. Cidade Universitária, Ilha do Fundão, Rio de Janeiro, RJ 21941-902, Brasil. ${ }^{2}$ Universidade Aberta da Terceira Idade - UnATI, Universidade Estadual do Rio de Janeiro - UERJ, Rio de Janeiro, Brasil.

\section{Received: 18 November 2014 Accepted: 12 October 2015}

\section{Published online: 22 October 2015}

\section{References}

1. Ahmed T, Haboubi N. Assessment and management of nutrition in older people and its importance to health. Clinical Interventions in Aging. 2010;5:207-16.

2. Caplan GA. Geriatric Medicine: an Introduction. Melbourne: 1st, IP Communications; 2014

3. Tsutsumi R, Tsutsumi YM, Horikawa YT, Takehisa Y, Hosaka T, Harada N, et al. Decline in anthropometric evaluation predicts a poor prognosis in geriatric patients. Asia Pac J Clin Nutr. 2012;21(1):44-51.

4. Adams NE, Bowie AJ, Simmance N, Murrary M, Crowe T. Recognition by Medical and nursing professionals of malnutrition and risk of malnutrition in elderly Hospitalised patients. Nutrition and Dietetics. 2008;65:144-50.

5. Abellan Van Kan G, Vellas B. Is the Mini Nutritional Assessment an appropriate tool to assess frailty in older adults? J Nutr Health Aging. 2011;15(3):159-61.

6. Vellas B, Villars H, Abellan G, Soto ME, Rolland Y, Guigoz Y, et al. Overview of the MNA-Its history and challenges. J Nutr Health Aging. 2006;10(6):456-63.

7. Abellan Van Kan G, Rolland Y, Bergman H, Morley JE, Kritchevsky SB, Vellas B. The I.A.N.A Task Force on frailty assessment of older people in clinical practice. J Nutr Health Aging. 2008;12(1):29-37.

8. Salva A, Coll-Planas L, Bruce S, De Groot L, Andrieu S, Abellan G, et al. Nutritional assessment of residents in long-term care facilities (LTCFs): recommendations of the task force on nutrition and ageing of the IAGG European region and the IANA. J Nutr Health Aging. 2009;13(6):475-83.

9. Lei Z, Qingyi D, Feng G, Chen W, Hock RS, Changli W. Clinical study of mininutritional assessment for older Chinese inpatients. J Nutr Health Aging. 2009;13(10):871-5.

10. Tsai AC, Ku PY, Tsai JD. Population-specific anthropometric cutoff standards improve the functionality of the Mini Nutritional Assessment without BMI in institutionalized elderly in Taiwan. J Nutr Health Aging. 2008;12(10):696-700.

11. Johansson L, Sidenvall B, Malmberg B, Christensson L. Who will become malnourished? A prospective study of factors associated with malnutrition in older persons living at home. J Nutr Health Aging. 2009;13(10):855-61.

12. Johansson $Y$, Bachrach-Lindström $M$, Carstensen J, Ek AC. Malnutrition in a homeliving older population: prevalence, incidence and risk factors. A prospective study. J ClinNurs. 2009;18(9):1354-64.

13. Cansado P, Ravasco P, Camilo M. A longitudinal study of hospital undernutrition in the elderly: comparison of four validated methods. J Nutr Health Aging. 2009;13(2):159-64.
14. Kaiser R, Winning K, Uter W, Lesser S, Stehle P, Sieber CC, et al. Comparison of two different approaches for the application of the mini nutritional assessment in nursing homes: resident interviews versus assessment by nursing staff. J Nutr Health Aging. 2009;13(10):863-9.

15. Pereira Machado RS, Santa Cruz Coelho MA. Risk of malnutrition among Brazilian institutionalized elderly: a study with the Mini Nutritional Assessment (MNA) questionnaire. J Nutr Health Aging. 2011;15(7):532-5

16. WHO: Expert Committee on Physical Status: the Use and Interpretation of Anthropometry Physical status: the use and interpretation of anthropometry: report of a WHO expert committee. WHO technical report series, 1995; 854

17. Guigoz Y, Vellas B, Garry PJ. Mini Nutritional Assessment: a practical tool for grading the nutritional state of the elderly patients. Facts Res Gerontol. 1994;suppl 2:15-60.

18. Fidanza F, Keller W. Nutritional Status Assessment. London: Chapman and Hall; 1991.

19. Kwok T, Whitelaw MN. The use of armspan in nutritional assessment of the elderly. J Am Geriatr Soc. 1991;39(5):492-6.

20. Chumlea WC, Guo SS, Vellas B, Guigoz Y. Techniques of assessing muscle mass and function (sarcopenia) for epidemiological studies of the elderly. $J$ Gerontol A BiolSci Med Sci. 1995;50(special issue):45-51.

21. Ferro-Luzzi A, Sette S, Franklin M, James WPT. A simplified approach to assessing adult chronic energy deficiency. European Journal of Clinical Nutrition. 1992:46:173-86

22. Burr B, Phillips K. Anthropometric Norms in the Elderly. Br. J. of Nutr.51: 165. Forbes, G.B. (1976). The Adult Decline in Lean Body Mass. Hum Biol. 1984;48:161-6.

23. Gallagher D, Heymsfield SB, Heo M, Jebb SA, Murgatroyd PR, Sakamoto Y. Healthy percentage body fat ranges: an approach for developing guidelines based on body mass index. Am J ClinNutr. 2000;72(3):694-701.

24. Woods A, Moshang J: Lowering the risks of diabetes, hypertension, and heart disease. Nursing 2005, Feb;Suppl:4-8; quiz 8-9. Review.

25. Tajima O, Nagura E, Ishikawa-Takata K, Ohta T. Two new potent and convenient predictors of mortality in older nursing home residents in Japan. Geriatr Gerontol Int. 2004:4:77-83.

26. Vandewoude MFJ, Alish CJ, Sauer AC, Hegazi RA. Malnutrition-sarcopenia syndrome: is this the future of nutrition screening and assessment for older adults? J Aging Res. 2012;651570:8.

27. Streiner DL, Norman GR. Health Measurement Scales: A Practical Guide to their Development and Use. 4th ed. Oxford: Oxford University Press; 2008.

28. Hosmer DW, Lemeshow S. Applied Logistic Regression. 2nd ed. New York: John Wiley and Sons; 2000.

29. Guigoz Y, Vellas B. The Mini Nutritional Assessment (MNA) for grading de nutritional state of the elderly patients: Presentation of the MNA, History and Validation. Nestlé Nutr Workshop Ser Clin Perform Program. 1999;1:3-12.

30. Omran ML, Morley JE. Assessment of protein energy malnutrition in older persons, Part II: laboratory evaluation. Nutrition. 2000;16:131.

31. Kuzuya M, Kanda S, Koike T, Suzuki Y, Satake S, Iguchi A. Evaluation of Mini-Nutritional Assessment for Japanese frail elderly. Nutrition. 2005;21(4):498-503.

32. Christensson L, Unosson M, Ek AC. Evaluation of nutritional assessment techniques in elderly people newly admitted to municipal care. Eur J ClinNutr. 2002;56(9):810-8

33. Delacorte RR, Moriguti JC, Matos FD, Pfrimer K, Marchinil JS, Ferriolli E. Mini-Nutritional Assessment score and the risk for undernutrition in free-living older persons. J Nutr Health Aging. 2004;8(6):531-4.

34. Donini LM, de Felice MR, Tassi L, de Bernardini L, Pinto A, Giusti AM, et al. A "proportional and objective score" for the Mini Nutritional Assessment in long-term geriatric care. J Nutr Health Aging. 2002;6(2):141-6.

35. Murphy MC, Brooks CN, New SA, Lumbers ML. The use of the MiniNutritional Assessment (MNA) tool in elderly orthopaedic patients. Eur J Clin Nutr. 2000;54(7):555-62.

36. Read JA, Crockett N, Volker DH, MacLennan P, Choy ST, Beale P, et al. Nutritional assessment in cancer: comparing the Mini-Nutritional Assessment (MNA) with the scored Patient-Generated Subjective Global Assessment (PGSGA). Nutr Cancer. 2005;53(1):51-6.

37. Thomas DR, Zdrowski CD, Wilson MM, Conright KC, Lewis C, Tariq S, et al. Malnutrition in subacute care. Am J ClinNutr. 2002;75(2):308-13. 
38. Thorsdottir I, Jonsson PV, Asgeirsdottir AE, Hjaltadottir I, Bjornsson S, Ramel A. Fast and simple screening for nutritional status in hospitalized, elderly people. J Hum Nutr Diet. 2005;18(1):53-60.

39. Visvanathan R, Penhall R, Chapman I. Nutritional screening of older people in a sub-acute care facility in Australia and its relation to discharge outcomes. Age Ageing. 2004;33(3):260-5.

40. Wikby K, Ek AC, Christensson L. Nutritional status in elderly people admitted to community residential homes: comparisons between two cohorts. J Nutr Health Aging. 2006;10(3):232-8.

\section{Submit your next manuscript to BioMed Central} and take full advantage of:

- Convenient online submission

- Thorough peer review

- No space constraints or color figure charges

- Immediate publication on acceptance

- Inclusion in PubMed, CAS, Scopus and Google Scholar

- Research which is freely available for redistribution 